\title{
CHRONOLOGY OF SWORDS WITH A CRESCENT-SHAPED TOP FROM MAEOTIAN BURIAL GROUNDS ${ }^{1}$
}

\author{
Natalya Yu. Limberis \\ Kuban State University, Krasnodar, Russian Federation \\ Ivan I. Marchenko \\ Kuban State University, Krasnodar, Russian Federation
}

\begin{abstract}
Introduction. Swords with a crescent-shaped top in Maeotian burials are meet less often than swords of the Sindic-Maeotian type from the $4^{\text {th }}-$ early $3^{\text {rd }}$ centuries BC. Methods and materials. The authors use the traditional typological method. The material comes from Maeotian sites. Analysis. There are three forms of crescent-shaped tops: classical crescent-shaped, V-shaped and half-ring top. In the sites of the right bank of the Kuban 10 swords without a cross-guard and 1 with a cross-guard, in the Trans-Kuban -8 swords without a crossguard and 2 swords with a cross-guard are known. The presence or absence of a cross-guard does not affect type chronology. The assemblages from burial grounds of IV Novolabinsk and Elisavetinskaya No. 1 hillforts date from the second quarter to the middle of the $3^{\text {rd }}$ century $\mathrm{BC}$. The dating is based on the type of the bronze mirror and Panticapaeum coins. Most narrowly dated burials come from burial grounds of Starokorsunskaya No. 2 and Lenin No. 3 hillforts located on the right bank of the Kuban river. The burials dating to within one quarter of the $2^{\text {nd }}$ century $\mathrm{BC}$ typically contained amphorae and black-glazed pottery, as well as certain types of Maeotian grey-clay vessels. Results. The chronological analysis indicates the appearance of swords with a crescent-shaped top of the Prokhorov type among Maeotian tribes under the influence of the Sarmatians. The earliest assemblages date from the second quarter to the middle of the $3^{\text {rd }}$ century BC. The chronology of more than a half of the burials does not go beyond the $2^{\text {nd }}$ century BC. The upper limit of the existence of swords with a crescent-shaped top can be determined within the early $1^{\text {st }}$ century BC.

Key words: Kuban Region, Maeotian culture, burial grounds, swords with a crescent-shaped top, chronology.

Citation. Limberis N.Yu., Marchenko I.I. Chronology of Swords with a Crescent-Shaped Top from Maeotian Burial Grounds. Vestnik Volgogradskogo gosudarstvennogo universiteta. Seriya 4. Istoriya. Regionovedenie. Mezhdunarodnye otnosheniya [Science journal of Volgograd State University. History. Area Studies. International Relations], 2020, vol. 25, no. 4, pp. 136-150. (in Russian). DOI: https://doi.org/10.15688/jvolsu4.2020.4.9
\end{abstract}

УДК 930.26(470+571)

ББК $63.48(2)$
Дата поступления статьи: 03.01.2020

Дата принятия статьи: 02.04.2020

ХРОНОЛОГИЯ МЕЧЕЙ С СЕРПОВИДНЫМ НАВЕРШИЕМ ИЗ МЕОТСКИХ МОГИЛЬНИКОВ ${ }^{1}$

\author{
Наталья Юрьевна Лимберис \\ Кубанский государственный университет, г. Краснодар, Российская Федерация \\ Иван Иванович Марченко \\ Кубанский государственный университет, г. Краснодар, Российская Федерация
}

Аннотация. Мечи с серповидным навершием в меотских погребениях встречаются значительно реже,
чем мечи синдо-меотского типа IV - начала III в. до н. э. Различаются три формы серповидного навершия:
классическое серповидное, V-образное и полукольцевое. В памятниках правобережной Кубани сейчас изве-
стно 10 мечей без перекрестия и 1 с перекрестием, в Закубанье - 8 мечей без перекрестия и 2 с прямым 
перекрестием. Наличие или отсутствие перекрестия не влияет на хронологию типа. Комплексы из могильников IV Новолабинского городища и Елизаветинского № 1 датируются второй четвертью - серединой III в. до н. э. по типу бронзового зеркала и пантикапейским монетам. Большинство узко датирующихся комплексов происходит из могильников городищ Старокорсунского № 2 и хут. Ленина № 3, расположенных на правом берегу реки Кубань. Погребения, датирующиеся в пределах четверти II в. до н. э., как правило, сопровождались амфорами и чернолаковой керамикой, а также определенными типами сероглиняных меотских сосудов. Хронологический анализ погребений, сопровождавшихся мечами с серповидным навершием, свидетельствует о появлении мечей с серповидным навершием прохоровского типа у меотских племен под влиянием сармат. Самые ранние погребения относятся ко второй четверти - середине III в. до н. э. Датировка большинства рассмотренных комплексов не выходит за рамки II в. до н. э. Верхнюю дату существования мечей с серповидным навершием у местного оседлого населения Прикубанья в настоящее время можно ограничить началом I в. до н. э. Хронология и типология мечей из могильников хут. Ленина № 1 и Старокорсунского № 2 разработаны Н.Ю. Лимберис, из остальных памятников - И.И. Марченко.

Ключевые слова: Прикубанье, меотская культура, могильники, мечи с серповидным навершием, хронология.

Цитирование. Лимберис Н. Ю., Марченко И. И. Хронология мечей с серповидным навершием из меотских могильников // Вестник Волгоградского государственного университета. Серия 4, История. Регионоведение. Международные отношения. - 2020. - Т. 25, № 4. - С. 136-150. - DOI: https://doi.org/10.15688/ jvolsu4.2020.4.9

Введение. Мечи с серповидным навершием в меотских погребениях встречаются значительно реже, чем мечи синдомеотского типа IV - начала III в. до н. э., выделенные К.Ф. Смирновым. Исследователь считал мечи с серповидным навершием без перекрестия поздними дериватами мечей синдо-меотского типа [14]. А.С. Скрипкин в работе, посвященной происхождению мечей прохоровского типа, отметил, что название типа «серповидных» мечей достаточно условно, так как навершия могут иметь разную степень прогнутости (от плавной до сильной) или бывают согнуты под разным углом - иногда их называют «рогатковидными» [13, с. 264]. Один из авторов данной статьи, рассматривая типологию и хронологию мечей из сарматских памятников Прикубанья, отнес мечи с серповидным навершием к отделу II, выделив в нем три типа. В тип 1 были объединены мечи с дуговидным или сломанным под углом перекрестием, в тип 2 - без перекрестия, в тип 3 - с прямым брусковидным перекрестием, так называемые прохоровские [8, с. 50-54; 10 , c. 87-91]. По мнению В.Р. Эрлиха, неправомерно объединять в один отдел разные по происхождению меотские и сарматские мечи [4, с. 149]. На наш взгляд, отнесение мечей с прямым перекрестием и серповидным навершием к особому отделу «мечей и кинжалов сарматских типов» их типоло- гию и хронологию не меняет, но априори устанавливает принадлежность этого оружия сарматским воинам.

Методы и материалы. Использование традиционного для археологической науки типологического метода дало возможность уточнить существующие классификации мечей с серповидным навершием. Для данной работы был использован материал из меотских памятников правобережья и левобережья Кубани, как опубликованный, так и неизвестный ранее исследователям.

Анализ. Рассматриваемые нами мечи из меотских погребений различаются формой навершия: есть классические серповидные, V-образные («рогатковидные») и полукольцевые, выделенные В.Р. Эрлихом. Мечи с серповидным (или полукольцевидным) навершием исследователь выделил в подотдел II отдела II мечей с антенным навершием, подразумевая, что серповидные навершия происходят от антенновидных [15, с. 83-84]. Нам представляется, что объединение в один отдел мечей с разной формой навершия некорректно. Также нужно отметить, что в меотских памятниках правобережной Кубани пока известны только мечи без перекрестия, в отличие от левобережья, где встречаются и мечи с перекрестием. Для уточнения датировки мечей с серповидным навершием из меотских памятников проанализируем имеющиеся находки. 
Наиболее ранний на правобережье Кубани меч с классическим серповидным навершием происходит из погребения 2 Елизаветинского могильника № 1 (раскопки А.В. Городцова 1934 г.). Этот комплекс К.Ф. Смирнов приводил в качестве доказательства того, что синдо-меотские мечи с брусковидным навершием «доживают» до второй половины III в. до н. э. Совместно с мечом была найдена пантикапейская монета второй половины III в. до н. э. [14, с. 43]. По описи Музея антропологии и этнографии, в этом погребении числятся четыре монеты, на трех из которых читается надпись «ПАN» и изображение лука и стрелы (МАЭ, инв. № 5266/1-4). В.А. Городцов сообщал, что из 17 монет, найденных в 1934 г., «8 монет сохранилось настолько хорошо, что А.Н. Зограф мог определить их время. Самая старшая из них относится к IV-III вв. все же остальные - к III в., причем одна из последних может относиться и к началу II в. до н. э.» [6, с. 75]. К сожалению, изображение на аверсе монет не читалось. Монеты типа «голова сатира / лук и стрела» с легендой ПАN датируются М.Г. Абрамзоном временем около 275250 гг. до н. э., а монеты с головой Аполлона на аверсе, такой же легендой и изображением на реверсе - временем около 200 150 гг. до н. э. [1, с. 101, 112, 209, кат. № 1483, 3197-3459]. Так как только одну монету из восьми А.Н. Зограф датировал началом II в. до н. э., у нас есть все основания 3 монеты из погребения 2 датировать 275-250 гг. до н. э., а сам комплекс - второй четвертью серединой III в. до н. э.

Еще один меч с серповидным навершием и слабоизогнутым перекрестием длиной 116 см происходит из погребения № 18/1931 г. (черепичная гробница) Елизаветинского городища № 1, которое Н.В. Анфимов датировал III в. до н. э. [2, с. 48]. Вместе с мечом были найдены лепной горшок и втульчатые трехлопастные наконечники стрел (несколько железных и один бронзовый) [5, с. 123 , рис. $1, K$, 1-4]. Мы не беремся по неточному рисунку определять тип бронзового наконечника стрелы, но его наличие в колчане позволяет ограничить верхнюю дату не позднее последней четверти III в. до н. э., так как в это время они уже полностью выходят из употребления.
Из раскопок могильника Старокорсунского городища № 2 сейчас известно три меча этого типа с разными вариантами серповидного навершия. Меч из погребения 188в (рис. 1, б) с V-образным навершием и удлиненно-треугольным, линзовидным в сечении клинком, судя по остаткам тлена, находился в деревянных ножнах. Основание клинка срезано почти под прямым углом к рукояти. Рукоятка в сечении прямоугольная, слегка расширяется к навершию и основанию клинка. Длина меча - 68 см, длина клинка -57 см, максимальная ширина клинка $-5,9$ см, длина рукояти $-11 \mathrm{~cm}$.

В этом погребении была встречена амфора (рис. 1,8$)$ прикубанской серии варианта II-B «старокорсунского» типа, дату которой мы ограничили второй четвертью II в. до н. э. $[9$, с. 268,269 , табл. 4,11$]$, а также сероглиняный трехручный канфар с шипами у верхних прилепов ручек на высоком коническом поддоне (рис. 1, 2). Хронология этого типа сосудов пока ограничивается второй четвертью II в. до н. э. [7, с- 229,237 , рис. 23,4 , рис. 40,5 , рис. 50,12$]$.

Еще один меч c V-образным навершием был найден в погребении 2053 (рис. 2, б). Клинок меча удлиненно-треугольный, линзовидный в сечении. Основание клинка срезано под прямым углом к рукояти. На основании клинка лежала узкая, тонкая железная пластинка от оковки ножен. Клинок был заключен в железные ножны, сверху обложенные деревом. Между железными ножнами и деревянной обкладкой была проложена ткань крупного плетения. Длина меча $-71,6$ см, длина клинка - 62,6 см, максимальная ширина клинка $6 \mathrm{~cm}$, длина рукояти - 9 см, ширина ножен 7,4 см (размеры даны по полевому чертежу).

В этом погребении были найдены амфоpa (рис. 2, 2) того же типа, что и в предыдущем погребении, и сероглиняный двуручный канфар на низком кольцевом поддоне (рис. 2, 5) последней четверти II в. до н. э. [7, с. 229,238 , рис. 23,4$]$.

Из погребения 3183 (рис. 3, 3) происходит меч с полукольцевым навершием. Клинок меча удлиненно-треугольный, уплощеннолинзовидный в сечении. Основание клинка срезано под тупым углом к рукояти. Длина меча -60 см, длина клинка $-47,5$ см, макси- 
мальная ширина клинка $-6,7$ см, длина рукояти $-8,3$ см. Трехручный сероглиняный канфар на кольцевом поддоне (рис. 3,2 ) из этого комплекса датируется широко - в пределах второй половины II в. до н. э. Более узкие хронологические рамки имеет миска с выступающим горизонтальным венчиком, орнаментированным зигзагом (рис. 3,5 ). Близкая ей аналогия происходит из погребения 4753 с амфорой прикубанской серии последней четверти II в. до н. э. [7, с. 229, 235, 237, рис. 39, 5, 7]. Этим временем, скорее всего, и следует датировать погребение 3183.

Два комплекса с мечами рассматриваемого типа были открыты в могильнике городища № 3 хут. Ленина. В богатом погребении 3 (раскоп VI 1983 г.) вместе с разнообразным инвентарем был найден меч с полукольцевым навершием (концы обломаны) и узким, равномерно сужающимся к концу клинком (рис. 4, 3). Восстановленная (в поле) длина меча - около $70 \mathrm{~cm}$, максимальная ширина клинка -4 см, длина рукоятки -9 см.

Комплекс датируется по родосской амфоре (рис. 4, 2) варианта вилланова поздней серии (I-E-2). На одной ручке - трехстрочное клеймо эпонима Аглумброта, на другой клеймо фабриканта Сосиласа и эмблема «цветок». Деятельность эпонима Аглумброта (период ІІІа) ограничивается 197 г. до н. э. [18, p. 124,192 , tabl. 6,19$]$. На этом основании хронологические рамки погребения можно ограничить первой четвертью II в. до н. э.

Второй меч из этого же могильника (погребение 14, раскоп II 1982 г.) - с классическим серповидным навершием и удлиненнотреугольным клинком, уплощенно-линзовидным в сечении (рис. 5,8 ). Основание клинка срезано под прямым углом к рукояти. Длина меча - 49,2 см, максимальная ширина клинка - 4,2 см, длина рукоятки - 10,2 см. Керамический комплекс погребения представлен сероглиняными сосудами меотского производства. Для датировки особенно показательна форма чашечки с горизонтально отогнутым краем (рис. 5, 2), характерная для второй половины II в. до н. э. [7, с. 239]. Этим периодом и предлагается датировать погребение.

Два меча с классическим серповидным навершием происходят из наших раскопок могильника городища Спорное. В погребе- нии 67 был найден меч с длинным прямым клинком, плавно сужающимся к острию (рис. 5, 9). Клинок в сечении линзовидный. На рукоятке сохранился древесный тлен от обкладок, а на клинке - от ножен. Длина меча (по графической реконструкции) - 63 см, длина рукояти - 10,6 см, максимальная ширина клинка $-4,8$ см.

Данных для узкой датировки недостаточно. Железный втульчатый наконечник стрелы с маленькой $(1,2$ см) головкой позволяет широко датировать этот комплекс III-II вв. до н. э.

В погребении 97 встречен меч с удлиненно-треугольным клинком, равномерно сужающимся к острию (рис. 5,10 ). Клинок в сечении линзовидный. Основание клинка срезано под тупым углом к рукояти. Рукоять в сечении прямоугольная. Длина меча $-64,4$ cм, длина клинка $-56,2$ см, длина рукояти $-8,2 \mathrm{~cm}$, максимальная ширина клинка $-6,2$ см.

При отсутствии керамики, ни найденный вместе с мечом железный наконечник копья (рис. 5,11 ), ни смешанный набор стеклянных бус, среди которых присутствуют типы, встречающиеся как в эллинистическую эпоху, так и в римское время, не дают возможности для узкой датировки погребения. Но его широкая хронология вряд ли выходит за пределы II-I вв. до н. э.

Следует упомянуть также погребение 4 некрополя Воронежского городища № 3 (раскопки Н.В. Анфимова 1966 г.), из которого происходят два меча с серповидным навершием длиной 75 см. Сероглиняные кувшин и миска из этого комплекса относятся ко II-I вв. до н. э.

Из 10 мечей с серповидным навершием, найденных в меотских памятниках Закубанья, 8 не имеют перекрестия. Так, в Тенгинском некрополе насчитывается 4 экземпляра без перекрестия из погребений 68, 140, 158 и 251. Согнутый в древности меч из погребения 68 (длиной 75,5 cм) имеет V-образное навершие, мечи из погребений 158 и 251 - классическое серповидное. Хронологию этих комплексов Е.А. Беглова и В.Р. Эрлих определили в пределах II в. до н. э. [4, с. 149, рис. 180, 1, 4, 10]. Меч из погребения 140 сохранился плохо, исследователи даже не приводят его рисунок. В статье, посвященной этому комплексу, Е.А. Беглова отмечает, что размеры меча не восстанавливаются ${ }^{2}$, а под ним сохранился 
тлен от деревянных ножен с золотой бутеролью, украшенной арочным орнаментом. Автор раскопок на основании хронологии чернолаковых мисочек, чернолакового и красноглиняных бальзамариев датирует погребение второй четвертью II в. до н. э. [3, с. 96, 104, рис. 11, 4].

Удлиненно-треугольный клинок меча из погребения 158 в верхней части украшен с двух сторон гравированным геометрическим орнаментом. На рукоятке сохранились следы от обмотки, на клинке - тлен от деревянных ножен. Длина меча -84 см, длина клинка 72 см, максимальная ширина клинка - 7,2 cм. На основании находки ручки родосской амфоры с круглым клеймом, которое, к сожалению, не прочитано, погребение датировано II в. до н. э. $[4$, с. 70,149 , рис. 90,8$]$.

Меч из погребения 251 также имеет удлиненно-треугольный клинок и короткую прямоугольную ручку, на которой сохранились следы деревянных накладок. Длина меча 65 см, длина клинка - около 54 см, максимальная ширина клинка $-5,4$ см. Набор из двух наконечников дротиков и наконечника копья, а также бронзовое кованое зеркало с боковой трапециевидной ручкой позволяют датировать этот комплекс II в. до н. э. [4, с. 112, 149, рис. 145, 12-16].

В двух погребениях Тенгинского могильника были встречены мечи с перекрестием [4, с. 149-150, рис. 180, 2, 9]. Из погребения 19 происходит меч с прямым перекрестием и классическим серповидным («дуговидным») навершием. Клинок прямой, с ребром жесткости. Сохранившаяся длина меча $-54 \mathrm{~cm}$, максимальная ширина клинка $-4,5$ см. Этот комплекс авторы датируют III-II вв. до н. э., хотя включили его в третью хронологическую группу второй половины II - первой четверти І в. до н. э. [4, с. 50,176 , рис. 15,16$]$.

Конское погребение 15 сопровождалось мечом с прямым перекрестием и V-образным навершием, клинок удлиненный треугольный, конец согнут. Сохранившаяся длина - не менее 60 см, ширина перекрестия - 5,4 см, ширина клинка в верхней части -5 см. Захоронение лошади, как считают исследователи, связано с погребением 224 и на этом основании включено в «промежуточную» хронологическую группу середины I в. до н. э. - первой половины І в. н. э. [4, с. 123, 176]. Правда, авторы монографии не приводят сведений, которые позволили им связать эти два захоронения в единый комплекс. Если только на основании их близкого расположения, то эта связь нам кажется более чем сомнительной. Дело в том, что сероглиняные кувшин и кружка, равно как и железные наконечники дротиков и копий, найденные в этих погребениях, занимают разные хронологические позиции [4, рис. $135,4,6,7$, рис. $157,8,4-6]$. Причем более ранние типы керамики и вооружения происходят из конского захоронения с мечом, дату которого, на наш взгляд, следует ограничить концом II в. до н. э., возможно, началом I в. до н. э.

В могильнике Псенафа известно три меча с классическим серповидным навершием, без перекрестия [16, кат. 53-55]. Из скопления 28 происходит меч (длина клинка 50 см), который В.Р. Эрлих, исходя из общей широкой хронологии мечей этого типа, отнес к III-II вв. до н. э., хотя вместе с мечом было встречено литое бронзовое зеркало типа $\mathrm{V}, 1$ $[17$, с. 311 , рис. 8,5$]$. Зеркала этого варианта, по И.И. Марченко, датируются II-I вв. до н. э. [11, с. 19]. Аналогичное зеркало происходит из погребения 339в могильника Старокорсунского городища № 2 (раскопки авторов 2015 г.) с амфорой прикубанской серии варианта II-А раннего выпуска, которая датируется второй четвертью II в. до н. э. [9, c. 261,266 , № 2-4, табл. 2, 2-4]. Таким образом, на данный момент время появления зеркал этого типа можно отнести ко второй четверти II в. до н. э. Других данных для датировки скопления 28 нет, поэтому вряд ли стоит удревнять его до ІІІ в. включительно.

В скоплении 44 вместе с мечом обнаружено простое бронзовое кованое зеркало типа V, 2. В.P. Эрлих справедливо датировал этот комплекс II в. до н. э., отмечая при этом, что время бытования зеркал этого варианта И.И. Марченко ограничивал I в. до н. э. - І в. н. э., не исключая и II в. до н. э. [17, с. 311 , рис. 8,6 ]. Новые материалы свидетельствуют о присутствии зеркал этого варианта в погребениях последней четверти II в. до н. э. вместе с сероглиняными канфарами на низком кольцевом поддоне. Датировка этого типа канфаров, в свою очередь, подкреплена амфорами [7, с. 238].

В погребении 37 могильника IV Новолабинского городища был найден меч с полу- 
кольцевым навершием, без перекрестия, с прямым клинком длиной около 85 см, плавно сужающимся к острию. Клинок шириной 6 см, в сечении линзовидный. Из этого комплекса происходит большое (диаметр - 18,8 см) литое бронзовое зеркало, на оборотной стороне которого нанесен орнамент в виде полуов. В описании Б.А. Раев и Г.Е. Беспалый отмечают, что к центру диска была припаяна ручка длиной 2 см, шириной 0,9 см. К сожалению, в таблице отсутствует рисунок ручки $[12$, с. 24 , табл. $37,5,9]$. Судя по размерам, это должна быть небольшая ручка в виде столбика, подобная сохранившимся на аналогичных зеркалах из меотских и сарматских погребений.

Такие зеркала с центральной ручкой в виде столбика с отверстием или шляпкой известны в комплексах Псенафа и в Тенгинском могильнике. При зеркалах типа I из тенгинских погребений 104 и 171 найдены отломанные ручки с отверстием на конце, которые крепились к оборотной стороне в центре диска. На диске зеркала из погребения 248 в центральной части имеется дырка от отломанной ручки. Оборотная сторона трех зеркал из погребений 104, 171 и 202 украшена гравированным орнаментом из полуов. К сожалению, в этих погребениях отсутствуют находки, которые позволили бы сузить хронологические рамки комплексов, в связи с чем исследователи ограничились замечанием, что комплексы с этими зеркалами являются «достаточно ранними в рамках Тенгинского могильника, то есть не позже конца III в. до н. э.», и включили их в первую хронологическую группу середины - третьей четверти III в. до н. э. [4, с. 161,175 , рис. $188,1-4$, рис. 199].

Три из четырех аналогичных зеркал (тип I, 1), найденных в могильнике Псенафа, украшены с тыльной стороны поясами гравированных концентрических кругов и поясом полуов [17, с. 307, рис. 1, 1-3]. Раньше этот тип зеркал датировался концом IV - третьей четвертью III в. до н. э. [11, с. 15]. В погребении 29 вместе с таким зеркалом встречены два кованых зеркала типов IV, 1a (с боковой ручкой без фестонов) и V, 2 (в виде простого кованого диска). На основании этих находок B.P. Эрлих предполагает, что зеркала типа I «продолжают существовать и позже, по крайней мере, во второй половине II в. до н. э.»
[17, с. 307]. Почему во второй половине, а не в первой, автор не уточняет. Нужно отметить, что это единственный, известный нам, случай запаздывания зеркал типа I, к тому же мы допускаем более раннюю датировку дисковидного зеркала типа V,2.

Зеркала, в центре которых сохраняются круглые отпечатки припоя от ручек, известны в меотских погребениях 1в, 68в и 242в Старокорсунского городища № 2, правда, они без орнамента. Погребение 1в по совместным находкам двух родосских амфор и аттического чернолакового канфара стиля «западного склона» с надписью ФI IIA $\Sigma$, нанесенной жидкой глиной, датируется серединой III в. до н. э. [7, с. 224 , рис. 2 , 9]. К концу IV - началу III в. до н. э. на основании находки книдской амфоры относится погребение 68в [7, с. 223, рис. 8, 17]. Погребение 242в по синопской амфоре варианта II-B с астиномным клеймом Деметрия сына Феогнета датируется концом первой четверти III в. до н. э. [8, с. 72, рис. 31,8$]$.

По нашему мнению, хронология зеркал типа I с центральной ручкой-столбиком позволяет ограничить наиболее вероятную датировку новолабинского погребения 37 пределами второй четверти - середины III в. до н. э.

Результаты. Таким образом, хронологический анализ меотских погребений, сопровождавшихся мечами с серповидным навершием, показывает, что самые ранние из них относятся ко второй четверти - середине III в. до н. э. Датировка большинства рассмотренных комплексов не выходит за рамки II в. до н. э. Верхнюю дату существования мечей с серповидным навершием у местного оседлого населения Прикубанья в настоящее время можно ограничить началом I в. до н. э. Ранее И.И. Марченко, рассматривая хронологию мечей с брусковидным и серповидным навершием, отмечал, что между этими типами существовала лакуна почти полвека, которую ему удалось сократить до четверти столетия [11, с. 51]. Новые материалы позволяют ликвидировать и эту лакуну.

Стоит остановиться и на вопросе генезиса мечей прохоровского типа. А.С. Скрипкин справедливо отмечает, что единой однолинейной эволюции мечей этого типа не существовало и на ранних этапах развитие форм наверший и перекрестий, приведших к появ- 


\section{АРХЕОЛОГИЯ РАННЕГО ЖЕЛЕЗНОГО ВЕКА}

лению мечей прохоровского типа, в различных регионах шло независимо друг от друга. В качестве доказательства существования ранней традиции изготовления клинкового оружия с серповидным навершием на Кубани исследователь приводит кинжал с почковидным перекрестием из погребения 85в могильника Старокорсунского городища № 2, которое датируется первой половиной VI в. до н. э. Второй кинжал с серповидным навершием и сегментовидным перекрестием из погребения 234в этого же могильника датируется концом VI - началом V в. до н. э. [13, с. 266-268, рис. $1,5,6]$. На наш взгляд, появление акинаков с такими навершиями в меотских древностях отнюдь не означает, что они стали отправной точкой в развитии мечей прохоровского типа в Прикубанье. Между этими мечами и клинковым оружием прохоровского типа существует большой хронологический разрыв. В IV - начале III в. до н. э. меоты использовали мечи синдо-меотского типа с брусковидным навершием без перекрестия. Хронологический анализ погребений с мечами из меотских памятников свидетельствует о появлении мечей с серповидным навершием прохоровского типа у местных племен под влиянием сармат.

\section{ПРИМЕЧАНИЯ}

${ }^{1}$ Работа выполнена в рамках проекта РФФИ, грант № 18-09-00619 «Военное дело меотов правобережья Кубани (VI в. до н. э. - III в. н. э.)». Чертежи амфор, их хронологическая и типологическая атрибуция выполены за счет гранта РНФ, проект № 18-18-00096 «Греческие амфоры (VII-II вв. до н. э.) с северных берегов Понта: создание музейных каталогов и электронной базы данных (АРЕ)».

The work was funded by RFBR, grant no. 1809-00619 "Military Affairs of the Maeotians of the Kuban Right Bank ( $6^{\text {th }}$ century BC $-3^{\text {rd }}$ century AD)". Drawings of amphorae, their chronological and typological attribution were carried out with a grant from the Russian Science Foundation, project No. 18-18-00096) "Greek amphorae(VII-II cent. BC) from the Northern shores of the Pontus: the creation of Museum catalogs and an interactive Database (APE)".

${ }^{2}$ В монографии, посвященной исследованию Тенгинского некрополя, указаны размеры этого меча: сохранившаяся длина -68 см, длина рукояти -9 см, ширина клинка -6 см $[4$, с. 61$]$. 


\section{ПРИЛОЖЕНИЕ}

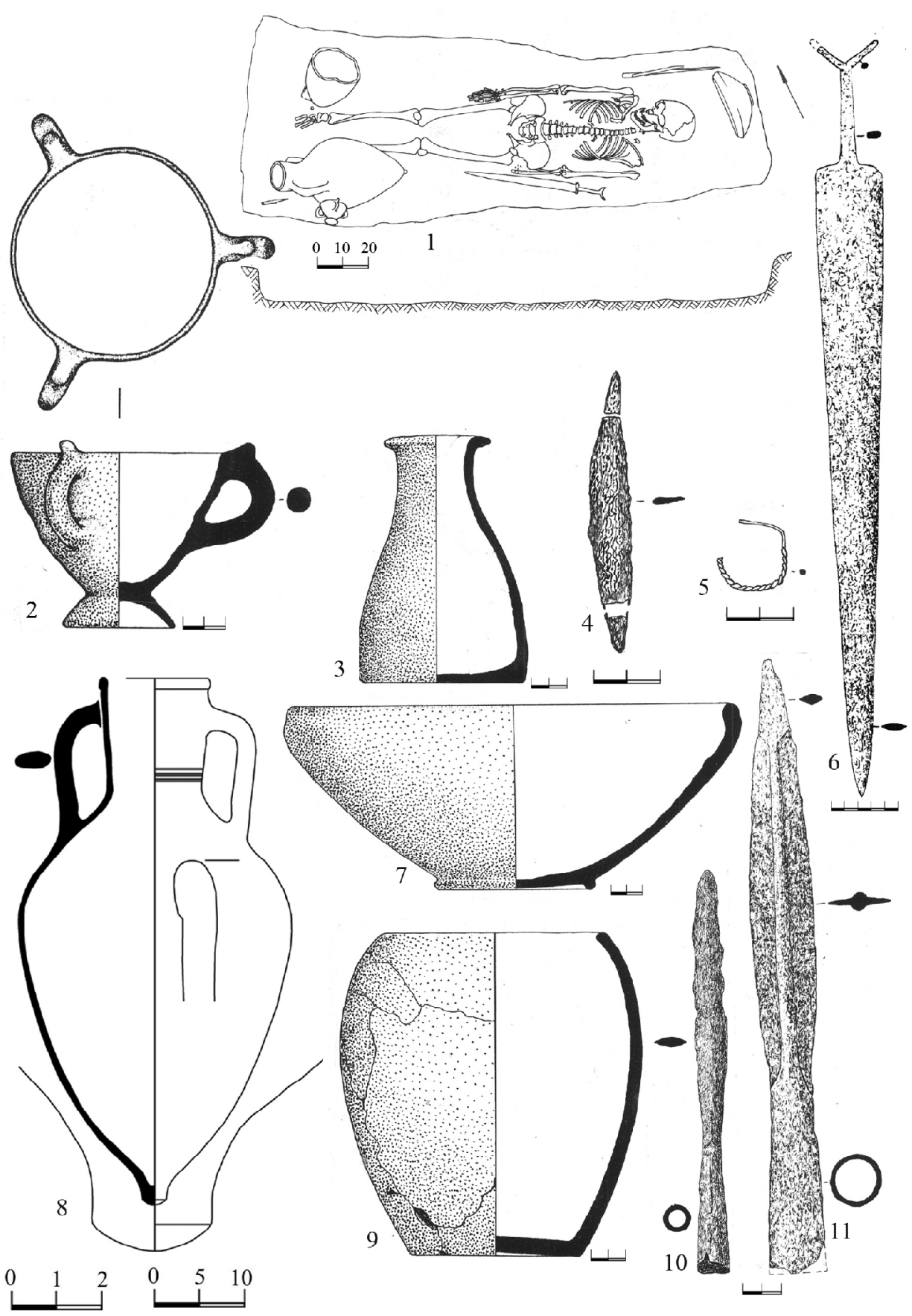

Рис. 1. Могильник Старокорсунского городища № 2, погребение 188в:

1 - план и разрез могильной ямы; 2 - канфар; 3 - курильница; 4 - нож; 5 - серьга; 6 - меч; 7 - миска; 8 - амфора; 9 - горшок; 10, 11 - наконечники копий (2, 3, 7-9 - керамика; 5 - бронза; 4, 6, 10, 11 - железо)

Fig. 1. Burial ground of Starkorsunskaya hillfort No. 2, burial 188в:

1 - plan and cut of the grave pit; 2 - kantharos; 3 - incense burner; 4 - knife; 5 - earring; 6 - sword; 7 - bowl; 8 - amphorae; 9 - pot; 10,11 - spearheads $(2,3,7-9$ - pottery; 5 - bronze; 4, 6, 10, 11 - iron) 

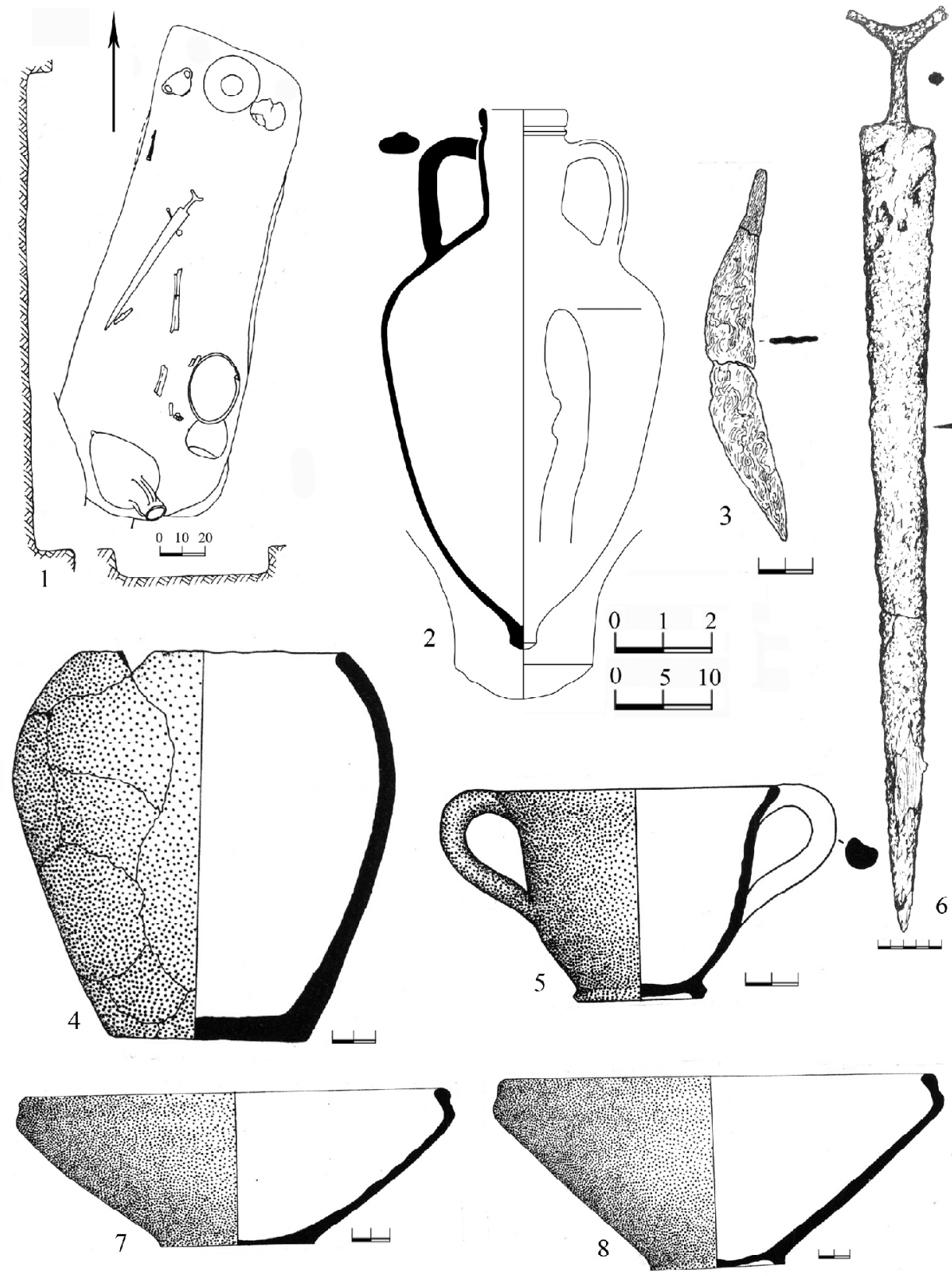

Рис. 2. Могильник Старокорсунского городища № 2, погребение 2053:

1 - план и разрезы могильной ямы; 2 - амфора; 3 - нож; 4 - горшок; 5 - канфар; 6 - меч; 7, 8 - миски (2, 4, 5, 7, 8- керамика; 3, 6 - железо)

Fig. 2. Burial ground of Starkorsunskaya hillfort No. 2, burial 2053:

1 - plan and cuts of the grave pit; 2 - amphorae; 3 - knife; 4 - pot; 5 - kantharos; 6 - sword; 7,8 - bowls $(2,4,5,7,8$ - pottery; 3,6 - iron) 

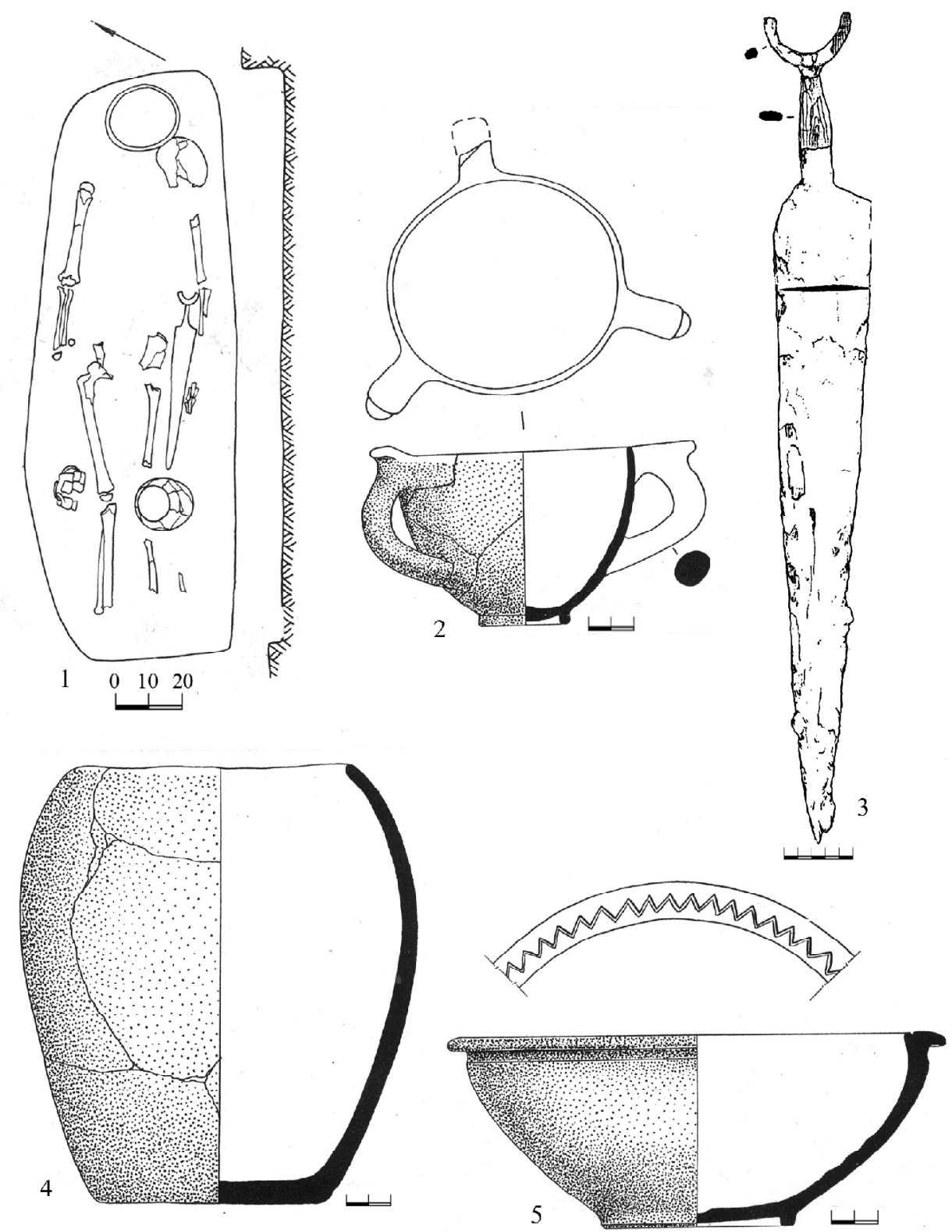

Рис. 3. Могильник Старокорсунского городища № 2, погребение 3183 :

1 - план и разрез могильной ямы; 2 - канфар; 3 - меч; 4 - горшок; 5 - миска (2, 4, 5 - керамика; 3 - железо)

Fig. 3. Burial ground of Starkorsunskaya hillfort No. 2, burial 3183:

1 - plan and cut of the grave pit; 2 - kantharos; 3 - sword; 4 - pot; 5 - bowl (2, 4, 5 - pottery; 3 - iron) 


\section{АРХЕОЛОГИЯ РАННЕГО ЖЕЛЕЗНОГО ВЕКА}
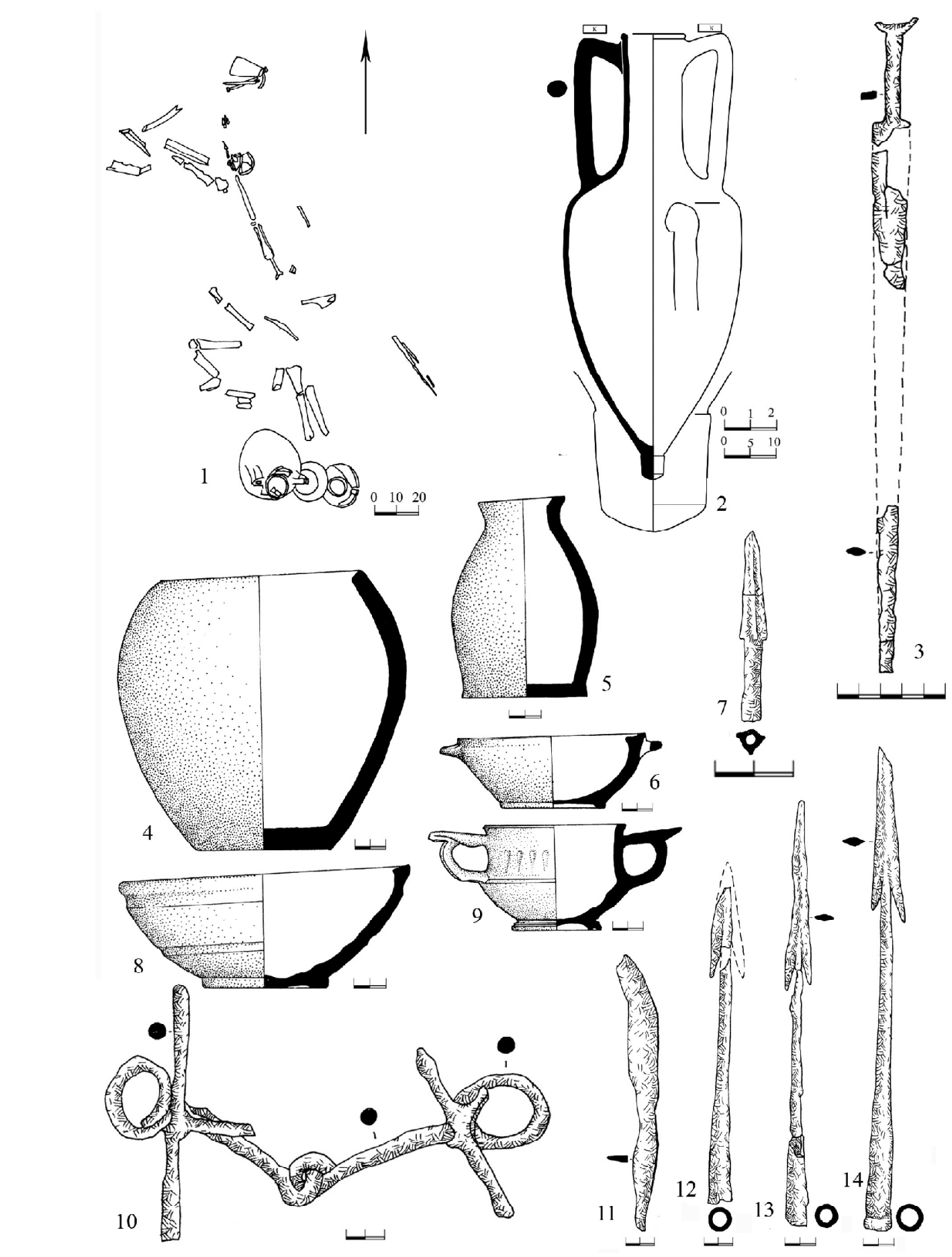

sing

Рис. 4. Могильник городища № 3 хуг. Ленина, погребение 3 (раскоп VI 1983 г.):

1 - план погребения; 2 - амфора; 3 - меч; 4 - горшок; 5 - курильница; 6 - чашечка; 7 - наконечник стрелы; 8 - миска; 9 - канфар чернолаковый; 10 - удила; 11 - нож; 12-14- наконечники дротиков (2, 4-6, 8, 9- керамика; 3, 7, 10-14-железо)

Fig. 4. Burial ground of Lenin hillfort No. 3, burial 3 (excavation VI 1983):

1 - plan of the burial; 2 - amphorae; 3 - sword; 4 - pot; 5 -incense burner; 6 -small bowl; 7 - arrowhead; 8 - bowl; 9 - black-glazed kantharos; 10 - bits; 11 - knife; $12-14$ - dart tips $(2,4-6,8,9$ - pottery; $3,7,10-14-$ iron $)$ 


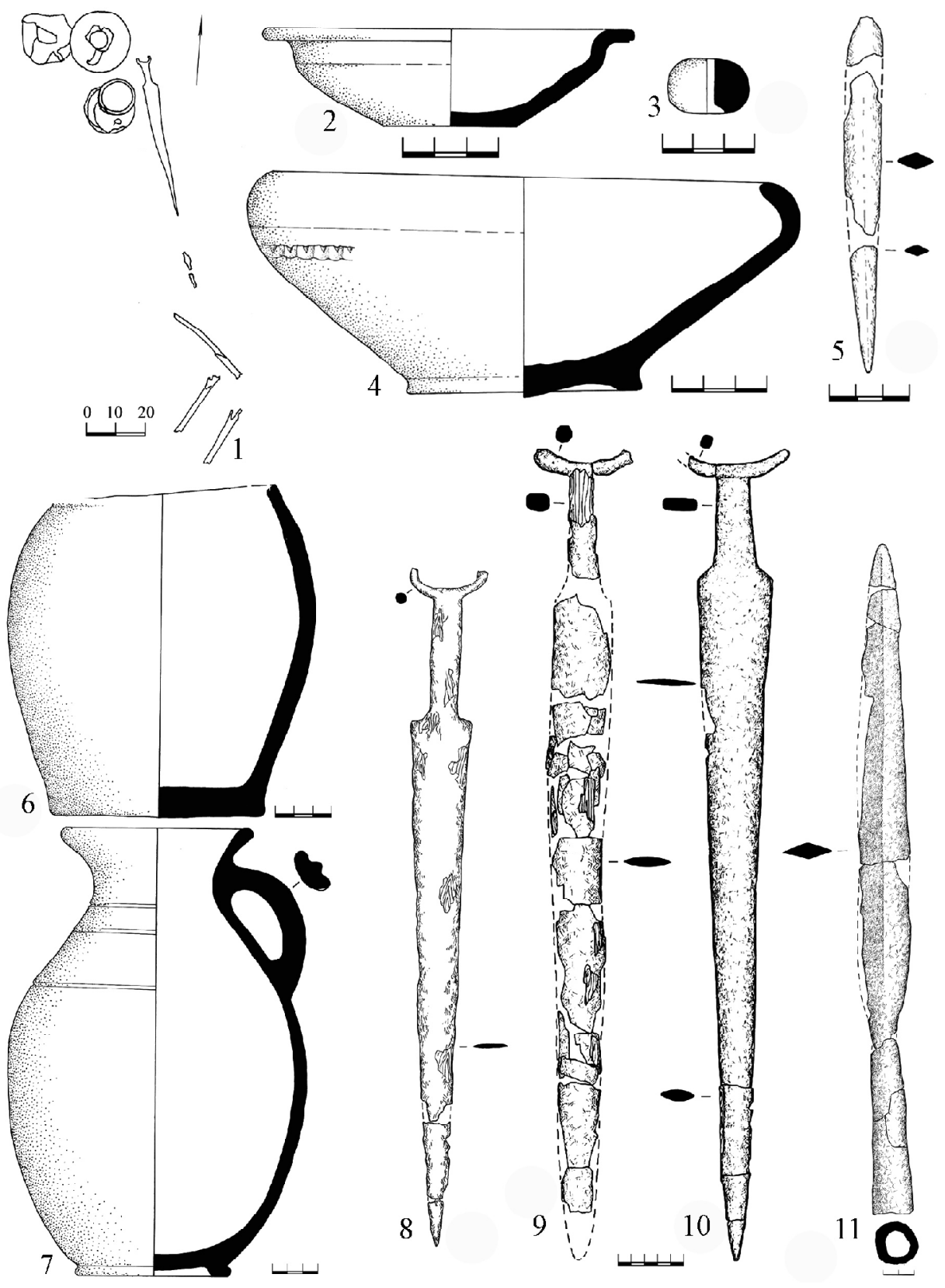

Рис. 5. Могильник городища № 3 хут. Ленина, погребение 14 (раскоп II 1982 г.)

( 1 - план погребения; 2 - чашечка; 3 - пряслице; 4 - миска; 5 - нож; 6 - горшок; 7 - кувшин; 8 - меч) и могильник городища Спорное (9- меч из погребения 67; 10,11 - меч и наконечник копья из погребения 97) (2-4, 6, 7- керамика; 5, 8-11- железо)

Fig. 5. Burial ground of Lenin hillfort No. 3, burial 14 (excavation II 1982)

( 1 - plan of the burial; 2 - small bowl; 3 - spindle; 4 - bowl; 5 - knife; 6 - pot; 7 - jug; 8 - sword) and the burial ground of Spornoye hillfort $(9$-sword from burial $67 ; 10,11$-sword and spearhead from burial 97) (2-4, 6, 7- pottery; $5,8-11-$ iron) 


\section{СПИСОК СОКРАЩЕНИЙ}

$A M A$ - Античный мир и археология. КСИА - Краткие сообщения Института археологии.

КСИИМК - Краткие сообщения Института материальной культуры.

$M A Э$ - Музей антропологии и этнографии.

МИАК - Материалы и исследования по археологии Кубани.

МИАСК - Материалы и исследования по археологии Северного Кавказа.

CЭ-Советская этнография.

\section{СПИСОК ЛИТЕРАТУРЫ}

1. Абрамзон, М. Г. Монетные клады времени Митридата VI Евпатора с хоры Фанагории / М. Г. Абрамзон, В. Д. Кузнецов - М. : Изд-во ИА РАН, 2015. - 382 с. - (Фанагория. Результаты археологических исследований ; т. 3 ).

2. Анфимов, Н. В. Археологические разведки по Среднему Прикубанью / Н. В. Анфимов // КСИИМК. - 1955. - № 60. - С. 45-53.

3. Беглова, Е. А. Первый ритуальный комплекс Тенгинского могильника / Е. А. Беглова // OPUS: Междисциплинарные исследования в археологии. 2004. - № 3. - C. 88-111.

4. Беглова, Е. А. Меоты Закубанья в сарматское время (по материалам Тенгинского грунтового могильника) / Е. А. Беглова, В. Р. Эрлих. - М. ; СПб. : Нестор-История, 2018. - 384 с.

5. Берлизов, Н. Е. Елизаветинский могильник № 1 (по материалам рукописного архива Н.В. Анфимова) / Н. Е. Берлизов, И. Н. Анфимов // МИАСК. 2006. - № 5. - С. 121-138.

6. Городцов, В. А. О результатах археологических исследований Елизаветинского городища и могильника в 1934 г. / В. А. Городцов // СЭ. - 1935. Вып. 3.-С.71-76.

7. Лимберис, Н. Ю. Хронология керамических комплексов с античными импортами из раскопок меотских могильников правобережья Кубани / Н. Ю. Лимберис, И. И. Марченко // МИАК. 2005. - № 5. - С. 219-324.

8. Лимберис, Н. Ю. Раскопки могильника Старокорсунского городища № 2 в 2006 г. / Н. Ю. Лимберис, И. И. Марченко // МИАК. - 2007. - № 7. С. $70-150$.

9. Лимберис, Н. Ю. Новая «прикубанская» серия эллинистических амфор / Н. Ю. Лимберис, И. И. Марченко, С. Ю. Монахов // АМА. - 2011. Вып. 15. - С. 265-283.

10. Марченко, И. И. Сарматы степей правобережья Нижней Кубани во второй половине
IV в. до н. э. - II в. н. э. (по материалам курганных погребений) : дис. ... канд. ист. наук / Марченко Иван Иванович. - Л., 1988. - 241 с.

11. Марченко, И. И. Сираки Кубани / И. И. Марченко. - Краснодар : Изд-во КубГУ, 1996. - 337 с.

12. Раев, Б. А. Курган скифского времени на грунтовом могильнике IV Новолабинского городища / Б. А. Раев, Г. Е. Беспалый. - Ростов н/Д : Изд-во ЮНЦРАН, 2006. - 110 c.

13. Скрипкин, А. С. О происхождении мечей прохоровского типа / А. С. Скрипкин // Проблемы сарматской археологии и истории : материалы IX Междунар. науч. конф. - Оренбург : Изд-во Оренбург. ГПУ, 2016. - С. 264-275.

14. Смирнов, К. Ф. О мечах синдо-меотского типа / К. Ф. Смирнов // КСИА. - 1980. - Вып. 162. C. $38-45$.

15. Эрлих, В. Р. Меотские мечи из Закубанья / В. Р. Эрлих // Древности Северного Кавказа и Причерноморья. - М. : Изд-во ГМВ, 1991. C. 77-99.

16. Эрлих, В. Р. Древности «Долины яблонь». Каталог выставки / В. Р. Эрлих. - М. : ГМВ, 2014. $144 \mathrm{c}$.

17. Эрлих, В. Р. Зеркала археологического комплекса Псенафа / В. Р. Эрлих // V «Анфимовские чтения» по археологии Западного Кавказа. - Краснодар : Вика-Принт, 2015. - С. 307-320.

18. Finkielsztejn, G. Chronologie détaillée et révisée des éponyms amphorique rhodiens, de 270 à 108 av. J.-C environ / G. Finkielsztejn // Premier bilan, British Arch. Rep., Int. ser. - Oxford : [s. n.], 2001.$260 \mathrm{p}$.

\section{REFERENCES}

1. Abramzon M.G., Kuznetsov V.D. Monetnye klady vremeni Mitridata VI Evpatora s khory Fanagori [The Coin Treasures of the Mithridat VI Evpator Time from the Chora of Phanagoria]. Moscow, IA RAN, 2015. 382 p. (Fanagoriya. Rezultaty arkheologicheskikh issledovaniy [Phanagoria. The Results of Archaeological Studies], vol. 3).

2. Anfimov N.V. Arkheologicheskie razvedki po Srednemu Prikubanyu [Archaeological Exploration in the Middle Kuban]. KSIIMK [Short Reports of the Institute of Material Culture], 1955, no. 60, pp. 45-53.

3. Beglova E.A. Pervyy ritualnyy kompleks Tenginskogo mogilnika [The First Ritual Assemblage of the Tenginskaya Burial Ground]. OPUS: Mezhdistsiplinarnye issledovaniya $v$ arkheologii [OPUS: Interdisciplinary Studies in Archaeology]. Moscow, Izd-vo Parallel, 2004, iss. 3, pp. 88-111.

4. Beglova E.A., Erlikh V.R.. Meoty Zakubanyav sarmatskoe vremya (po materialam Tenginskogo 
gruntovogo mogilnika [Maeotians of the Trans-Kuban Region in the Sarmatian Time (According to the Materials of Tenginskaya Burial Ground)]. Moscow, Saint Petersburg, Nestor-Istoriya Publ., 2018. 384 p.

5. Berlizov N.E., Anfimov I.N. Elizavetinskiy mogilnik № 1 (po materialam rukopisnogo arkhiva N.V. Anfimova) [Elithabetian Burial Ground No 1 (Based on the Materials of the Manuscript Archive of N.V. Anfimov]. MIASK [Materials and Research on Archaeology of the North Caucasus], 2006, no. 5, pp. 121-138.

6. Gorodtsov V.A. O rezultatakh arkheologicheskikh issledovaniy Elizavetinskogo gorodishcha i mogilnika v 1934 g. [About the Results of the Archaeological Excavations of the Elisavetinskaya Hillfort and Burial Ground in 1934]. SE [Soviet Ethnography], 1935, iss. 3, pp. 71-76.

7. Limberis N.Yu., Marchenko I.I. Khronologiya keramicheskikh kompleksov s antichnymi importami iz raskopok meotskikh mogilnikov pravoberezhya Kubani [Chronology of the Ceramics Assamblages with Antique Imports from the Excavations of the Maeotian Burial Grounds on the Right Bank of the Kuban River]. MIAK [Materials and Studies on the Kuban Region Archaeology], 2005, no. 5, pp. 219-324.

8. Limberis N.Yu., Marchenko I.I. Raskopki mogilnika Starokorsunskogo gorodishcha № $2 \mathrm{v}$ $2006 \mathrm{~g}$. [The Excavations at the Burial Ground of the Starokorsunskaya Hillfort No 2 in 2006]. MIAK [Materials and Studies on the Kuban Region Archaeology], 2007, no. 7, pp. 70-150.

9. Limberis N.Yu., Marchenko I.I., Monakhov S.Yu. Novaya «prikubanskaya» seriya ellinisticheskikh amfor [The New Series of Hellenistic Amphorae from Kuban Region]. AMA [Ancient World and Archaeology], 2011, iss. 15, pp. 265-283.

10. Marchenko I.I. Sarmaty stepey pravoberezhya Nizhney Kubani vo vtoroy polovine $I V$ v. do n. e. II v. n. e. (po materialam kurgannykh pogrebeniy): dis. ... kand. ist. nauk [Sarmatians of the Steppes on the Lower Kuban Right Bank in the Second Half of the $4^{\text {th }}$ Cent. $\mathrm{BC}-2^{\text {nd }}$ Cent. $\mathrm{AD}$ (According to the Materials of the Burial Mounds). Cand. hist. sci. diss.]. Leningrad, 1988. $241 \mathrm{p}$.

11. Marchenko I.I. Siraki Kubani [Siraci of the Kuban River Basin]. Krasnodar, KubGU, 1996. 337 p.

12. Raev B.A., Bespalyy G.E. Kurgan skifskogo vremeni na gruntovom mogilnike IV Novolabinskogo gorodishcha [The Mound of the Scitian Time in the Burial Ground of the IV Novolabinsk Hillfort]. Rostovon-Don, Izd-vo YuNTs RAN, 2006. 110 p.

13. Skripkin A.S. O proiskhozhdenii mechey prokhorovskogo tipa [The Origin of the Swords of the Prokhorovka Type]. Problemy sarmatskoy arkheologii i istorii: materialy IX Mezhdunar. nauch. konf. [Problems of the Sarmatian Archaeology and History. Proceedings of the $9^{\text {th }}$ International Scientific Conference ]. Orenburg, Izd-vo Orenburgskogo GPU, 2016, pp. 264-275.

14. Smirnov K.F. O mechakh sindo-meotskogo tipa [About the Swords of the Sindic-Maeotian Type]. KSIA [Brief Communications of the Institute of Archaeology], 1980, iss. 162, pp. 38-45.

15. Erlikh V.R. Meotskie mechi iz Zakubanya [The Maeotian Swords from the Trans-Kuban Region]. Drevnosti Severnogo Kavkaza i Prichernomorya [Antiquities of Northern Caucasus and Black Sea Region] Moscow, Izd-vo GMV, 1991, pp. 77-99.

16. Erlikh V.R. Drevnosti «Doliny yablon». Katalog vystavki [Antiquities of "The Valley of the Apple Trees". Exhibition Catalogue]. Moscow, GMV, 2014. 144 p.

17. Erlikh V.R. Zerkala arheologicheskogo kompleksa Psenafa [The Mirrors of the Psenath Archaeological Complex]. V «Anfimovskie chteniya» po arkheologii Zapadnogo Kavkaza [5 $5^{\text {th }}$ "Anfimov's Reading" on the Archaeology of the West Caucasus]. Krasnodar, Vika-Print Publ., 2015, pp. 307-320.

18. Finkielsztejn G. Chronologie détaillée et révisée des éponyms amphorique rhodiens, de 270 à 108 av. J.-C environ. Premier bilan, British Arch. Rep., Int. ser. Oxford, [s. n.], 2001. 260 p. 


\section{АРХЕОЛОГИЯ РАННЕГО ЖЕЛЕЗНОГО ВЕКА}

\section{Information About the Authors}

Natalya Yu. Limberis, Senior Researcher, Scientific Research Institute of Archaeology, Kuban State University, Stavropolskaya St, 149, 350040 Krasnodar, Russian Federation, meot@mail.ru, https://orcid.org/0000-0003-0395-315X

Ivan I. Marchenko, Candidate of Sciences (History), Associate Professor, Professor, Department of World History and International Relations, Kuban State University, Stavropolskaya St, 149, 350040 Krasnodar, Russian Federation, meot@mail.ru, https://orcid.org/0000-0001-7319-5214

\section{Информация об авторах}

Наталья Юрьевна Лимберис, старший научный сотрудник НИИ археологии, Кубанский государственный университет, ул. Ставропольская, 149, 350040 г. Краснодар, Российская Федерация, meot@mail.ru, https://orcid.org/0000-0003-0395-315X

Иван Иванович Марченко, кандидат исторических наук, доцент, профессор кафедры всеобщей истории и международных отношений, Кубанский государственный университет, ул. Ставропольская, 149, 350040 г. Краснодар, Российская Федерация, meot@mail.ru, https://orcid.org/0000-0001-7319-5214 